\section{Evaluation of the Soil Vulnerability Index for artificially drained cropland across eight Conservation Effects Assessment Project watersheds}

C. Baffaut, S. Lohani, A.L. Thompson, A.R. Davis, N. Aryal, D.L. Bjorneberg, R.L. Bingner, S.M. Dabney, L.F. Duriancik, D.E. James, K.W. King, S. Lee, G.W. McCarty, L.A. Pease, M.L. Reba, A.M. Sadeghi, M.D. Tomer, M.R. Williams, and L.M.W. Yasarer

Abstract: The USDA Natural Resources Conservation Service (NRCS) has proposed the Soil Vulnerability Index (SVI) as a standard tool to classify inherent soil vulnerability of cropland to loss of sediment and nutrients by runoff and leaching. The tool uses soil properties and topography, and does not consider crop management, except for the presence of artificial surface or subsurface drainage. For artificially drained cropland, SVI vulnerability to runoff remains unchanged but vulnerability to leaching is raised by two classes out of four to reflect the increased risk of nitrate $\left(\mathrm{NO}_{3}\right)$ transport. The SVI was reviewed within different contexts, but there is a need for SVI evaluation when artificial drainage is present. Thus, the objectives of this evaluation were to (1) evaluate SVI vulnerability to runoff and leaching for artificially drained cropland, and (2) propose changes to the SVI ruleset based on the findings of Objective 1. The SVI was evaluated for eight sites with artificial drainage located in regions ranging from Idaho to Maryland. Seven sites were watersheds ranging in size from 600 to 113,600 ha, with $44 \%$ to $84 \%$ cropland consisting of row crops or small grains. The eighth site consisted of six fields ranging from 7 to 30 ha in size. Consistency between SVI vulnerability, hydrologic processes that take place on the landscape, and outcomes such as crops grown were examined, using the accumulated experience and knowledge of the coauthors of this paper. Overall, SVI vulnerability to runoff and leaching was consistent with earlier research for sites with artificial subsurface drainage unless rainfall intensities were greater than they are in the Upper Mississippi and Ohio-Tennessee River basins. SVI vulnerability to leaching was greater than expected in case of surface drainage. In addition, complex soil map units can cause incorrect vulnerability classification at field scale. At the watershed or regional scale, the leaching component should be considered both with and without artificial drainage so that the causes of the vulnerability (permeable soils or artificial drainage) can be distinguished.

Key words: Conservation Effects Assessment Project (CEAP)—erosion—leaching—nutrient loss-surface runoff-targeting

Edge-of-field sediment and nutrient losses can and often do contribute to water quality impairments of surface water in agroecosystems (Alexander et al. 2008; Smith et al. 2018). Vulnerability of a field to soil and nutrient losses has multiple causes including soil physical characteristics, topography, climate, and crop management. Among those, soil physical characteristics and topography change very slowly; they are inherent to the site. For the purpose of a conservation plan, and time resources for such assessment may be limited. The intent of the USDA Natural Resources Conservation Service (NRCS) was to develop an assessment tool that is rather fast and for which data are publicly and easily available. For large watersheds or regions, computer simulation models have been used to determine priorities and plan for conservation needs. Those models are often complex and cannot be implemented without specialized technical support and time resources. Assessment

Claire Baffaut is a hydrologist at the USDA Agricultural Research Service (ARS) Cropping Systems and Water Quality Research Unit, Columbia, Missouri. Sapana Lohani is a postdoctoral scholar in the Department of Biology, University of Nevada-Reno, Reno, Nevada. Allen L. Thompson is a professor in the Department of Bioengineering, University of Missouri, Columbia, Missouri. Austin R. Davis is a graduate student in the Department of Bioengineering, University of Missouri, Columbia, Missouri. Niroj Aryal is an assistant professor of biological engineering in the Department of Natural Resources and Environmental Design, North Carolina Agricultural and Technical State University, Greensboro, North Carolina. David L. Bjorneberg is a soil scientist at the USDA ARS, Northwest Irrigation and Soils Research Laboratory, Kimberly, Idaho. Ronald L. Bingner, Seth M. Dabney, and Lindsey M.W. Yasarer are agricultural engineer, agronomist, and hydrologist, respectively, at the USDA ARS National Sedimentation Laboratory, Oxford, Mississippi. Lisa F. Duriancik is the Conservation Effects Assessment Project (CEAP) Watershed Assessment Studies Component leader at the USDA Natural Resources Conservation Service (NRCS) Resource Assessment Division, Beltsville, Maryland. David E. James and Mark D. Tomer are a geographic information specialist and soil scientist, respectively, at the USDA ARS National Laboratory for Agriculture and the Environment, Ames, lowa. Kevin W. King is research leader and agricultural engineer at the Soil Drainage Research Unit, USDA ARS, Columbus, Ohio. Sangchul Lee is a postdoctoral research associate in the Department of Environmental Sciences and Technology at the University of Maryland, College Park, Maryland, and with the USDA ARS, Hydrology and Remote Sensing Laboratory, Beltsville, Maryland. Gregory W. McCarty and Ali M. Sadeghi (retired) are soil scientists at the USDA ARS Hydrology and Remote Sensing Laboratory, Beltsville, Maryland. Michele L. Reba is a hydrologist at the USDA ARS Delta Water Management Research Unit, Jonesboro, Arkansas. Mark R. Williams is an agricultural engineer at the USDA ARS National Soil Erosion Research Unit, West Lafayette, Indiana. Lindsay A. Pease is an assistant professor in the Department of Soil, Water, and Climate at the University of Minnesota, Crookston, Minnesota. 
tools that are simple, quickly calculated, and based on data that are public and easily accessible at multiple spatio-temporal scales are an asset to resource-limited watershed groups and planning agencies.

The idea of inherent soil vulnerability was proposed by NRCS to evaluate the potential of cropland to contribute to sediment and nutrient loss via surface runoff, artificial drainage, and leaching (USDA NRCS 2012). Runoff and leaching are the two central components of the Soil Vulnerability Index (SVI). Each component classifies soil vulnerability into one of four categories: low, moderate, moderately high, or high, based on soil properties and slope (tables 1 and 2). The index is linked to water quality outcomes, not productivity or economic outcomes. The SVI describes the inherent vulnerability of soil resources to crop production, i.e., it does not take cropping system, crop management, or conservation practices into account, except for the presence of artificial drainage. NRCS designed the SVI as a conservation-planning tool at watershed scale to identify locations of highest vulnerability, or at field scale to assess the conservation needs of a specific field. Thus, the SVI should be consistent within a watershed or a region such that soil runoff or leaching vulnerability class is consistent with loss of sediment and nutrients by runoff or leaching for similar land cover and land management.

The SVI was developed using model results from the Conservation Effects Assessment Project (CEAP) study for cropland in the Upper Mississippi River basin and the Ohio-Tennessee River basin as described by Thompson et al. (2020). The Agricultural Policy Environmental Extender (APEX; Wang et al. 2012) was used to simulate runoff, leached or percolated water, and sediment loss for the Natural Resource Inventory data points used in the CEAP cropland study (USDA NRCS 2012). Three driving factors from the SSURGO database (Soil Survey Staff 2018) were statistically tested against these simulated variables: hydrologic soil group, slope category, and soil erodibility (Revised Universal Soil Loss Equation [RUSLE] K-factor). These three factors defined the low, moderate, moderately high, and high vulnerability classes for runoff and leaching (tables 1 and 2).

Previous studies have evaluated the SVI by comparing cropland SVI classification with modeling results and expert assessment

\section{Table 1}

Definition of the runoff component of the Soil Vulnerability Index.

\begin{tabular}{|c|c|c|c|c|}
\hline \multirow[b]{2}{*}{ Soil runoff potential } & \multicolumn{4}{|c|}{ Hydrologic soil group* } \\
\hline & $\mathbf{A}$ & B & C & D \\
\hline Low & All area & Slope $<4$ & Slope $<2$ & $\begin{array}{l}\text { Slope }<2 \\
\text { K-factor }+<0.28\end{array}$ \\
\hline Moderate & None & $\begin{array}{l}4 \leq \text { slope } \leq 6 \\
\text { K-factor }<0.32\end{array}$ & $\begin{array}{l}2 \leq \text { slope } \leq 6 \\
\text { K-factor }<0.28\end{array}$ & $\begin{array}{l}\text { Slope }<2 \\
\text { K-factor } \geq 0.28\end{array}$ \\
\hline Moderately high & None & $\begin{array}{l}4 \leq \text { slope } \leq 6 \\
\text { K-factor } \geq 0.32\end{array}$ & $\begin{array}{l}2 \leq \text { slope } \leq 6 \\
\text { K-factor } \geq 0.28\end{array}$ & $2 \leq$ slope $\leq 4$ \\
\hline High & None & Slope $>6$ & Slope $>6$ & Slope $>4$ \\
\hline
\end{tabular}

Note: Slope measured as percentage.

*In case of dual hydrologic soil group classification, use the classification in undrained conditions. †K-factor refers to the soil erodibility factor of the Revised Universal Soil Loss Equation.

\section{Table 2}

Definition of the leaching component of the Soil Vulnerability Index.

\begin{tabular}{lllll}
\hline \multirow{2}{*}{$\begin{array}{l}\text { Soil } \\
\text { leaching potential* }\end{array}$} & A & B & C & D D \\
\hline Low & None & None & None & $\begin{array}{l}\text { All except } \\
\text { organic soils } \\
\text { Moderate }\end{array}$ \\
None & $\begin{array}{l}\text { Slope } \leq 12 \text { and } \\
\text { K-factor } \neq \geq 0.24 \\
\text { or slope }>12\end{array}$ & $\begin{array}{l}\text { All except } \\
\text { organic soils }\end{array}$ & None \\
Moderately high & Slope $>12$ & $\begin{array}{l}3 \leq \text { slope } \leq 12 \\
\text { and K-factor } \\
\text { High }\end{array}$ & None & None \\
& $\begin{array}{l}<\text { Slope } \leq 12 \\
\text { or soils } \\
\text { classified } \\
\text { as organic } \\
\text { soils }\end{array}$ & $\begin{array}{l}\text { K-factor }<0.24 \\
\text { or soils } \\
\text { classified as } \\
\text { organic soils }\end{array}$ & $\begin{array}{l}\text { Soils classified } \\
\text { as organic soils }\end{array}$ & $\begin{array}{l}\text { Soils classified } \\
\text { as organic soils }\end{array}$ \\
\hline
\end{tabular}

Note: Slope measured as percentage.

*If the coarse fragment content of the soil is greater than $30 \%$ by weight, the soil leaching vulnerability is increased two classes. If the coarse fragment content is greater than $10 \%$ but less than $30 \%$, the soil leaching vulnerability is increased one class.

†Artificial drainage of any kind increases leaching vulnerability by two classes. In case of dual hydrologic soil group classification, use the classification in undrained conditions.

$\ddagger K$-factor refers to the soil erodibility factor of the Revised Universal Soil Loss Equation.

in two watersheds. In the Goodwater Creek Experimental Watershed (Chan et al. 2017), testing of the SVI focused on surface runoff because of the restrictive soil layer for $>90 \%$ of the watershed. SVI vulnerability to runoff was consistent with modeling results. In the Upper Choptank watershed, Lee et al. (2018) found that the SVI runoff component was useful for pollutants adsorbed to soil particles (e.g., organic nitrogen $[\mathrm{N}]$ ) while the SVI leaching component was more useful for dissolved pollutants that are more likely to infiltrate (e.g., nitrate $\left[\mathrm{NO}_{3}\right]-\mathrm{N}$ ). In addition, the leaching component of the SVI performed better for the poorly drained soils than for the well-drained soils. For cropland underlain by well-drained soils, model leaching results were highly sensitive to a soil water content characteristic (i.e., gravitational water) (Lee et al. 2018)

The SVI was developed for all the cropland of the United States and needs to be evaluated across a wide range of soils, cropping systems, climate, and topography. To complement the two evaluation studies mentioned above, the network of CEAP watershed studies (Duriancik et al. 2008) offers an opportunity to evaluate the SVI across a range of physiographic regions in the United States. In some of these water- 
sheds, artificial drainage is a dominant component of cropland hydrology. Without it, crop production would be impossible or less profitable (Fausey et al. 1995). The published literature includes numerous studies that address the effects of artificial drainage on the flow paths and water quality, including a decrease of surface runoff (Bengtson et al. 1995; Bengtson and Carter 2004; Istok and Kling 1983; Irwin and Whitely 1983), a decrease in soil and nutrient loss from surface runoff (Bengtson et al. 1995), and an increase in $\mathrm{NO}_{3}$ leaching from the soil profile to the drainage system (Bhattarai et al. 2009; Keller et al. 2008; King et al. 2016) and to the receiving ditch or stream (Tomer et al. 2008). In some cases, there was no overall reduction of water discharged to receiving streams because an equivalent increase in lateral subsurface flow counterbalanced the reduction in surface runoff (Bosch et al. 2012). Subsurface drainage systems can also carry some phosphorus $(\mathrm{P})$ in dissolved and total forms. This is especially true when preferential or macropore flow transport $\mathrm{P}$ from the top soil layers to the subsurface drain (Stamm et al. 1998; Smith et al. 2015). The SVI addresses these changes in flow and nutrient pathways by increasing the leaching risk by two classes when artificial drainage is present (USDA NRCS 2012).

Given the importance of artificial drainage in agriculture, and the impact that artificial drainage has on water quality, there was a need to evaluate the SVI specifically for artificially drained land. Companion articles in this issue address other aspects of SVI evaluation. In particular, Thompson et al. (2020) discuss the theoretical basis and the development of the SVI. The objectives of this study were to (1) evaluate SVI vulnerability to runoff and leaching for artificially drained cropland, and (2) propose changes to the SVI ruleset based on the findings of Objective 1. For this study, we used a multiple site analysis to understand the factors that affect SVI accuracy and consistency. We further determined when and to what extent the SVI was useful to assess cropland soil vulnerability, and suggested potential improvements to the SVI.

\section{Materials and Methods}

Sites Description. The CEAP watersheds selected to evaluate the SVI (figure 1) were a subset of all the CEAP Watershed Assessment Studies (Duriancik et al. 2008): eight CEAP watersheds for which artificial drainage was a significant aspect of cropland management (table 3). These watersheds represent a variety of climate and soil conditions. Most of the cropland (land used for row crop production) in these watersheds is relatively flat (less than $2 \%$ slope; table 4 ), but cropping systems, climate, and soils reflect a variety of physiographic conditions (table 3). While all these watersheds are artificially drained, the drainage methods vary from shallow and deep surface ditches to subsurface drains. Surface drainage ditches remove surface-ponded water and excess moisture in the top soil layer and bring that water to receiving streams (Strock et al. 2018). Subsurface systems drain water from the intermediate soil layers, which then encourage infiltration from the soil surface into the soil profile.

Shallow or deep ditches artificially drain cropland at the Arkansas Delta sites and in the Beasley Lake, Upper Choptank, and Upper Snake Rock watersheds (table 3). Shallow surface ditches $(<30 \mathrm{~cm})$ surround the fields and discharge into a main drainage ditch via a drop pipe at the Arkansas Delta site and in Beasley Lake watershed. The Delta site includes six pairs of fields monitored for runoff, sediment, and nutrient losses. These six pairs were named after the town located near them along with a management descriptor when needed. Aryal et al. (2018) described the Caraway and Manila fields; annual reports describe the Leachville (Reba and Aryal 2018a), Burdette Precision level, Burdette Zero, and Marked Tree (Reba and Aryal 2018b) fields. Each pair includes two hydrologically separate fields ranging in size from 7 to 30 ha: one field kept as control and one managed under a conservation practice. In the Upper Choptank, drainage consists of an extensive network of open face, 2 to $3 \mathrm{~m}$ deep and 5 to $7 \mathrm{~m}$ wide ditches that capture surface runoff and some but not all subsurface flow. Some fields have multiple ditches, typically a combination of shallow and deep ditches. In these flat crop fields, runoff generated in the flat depressions is collected and directed toward the streams by drainage ditches, along with the sediment and dissolved nutrients. The Upper Snake Rock site differs from the other sites in that cropland is heavily irrigated with surface water diverted from the Snake River to compensate for the very low annual rainfall (271 mm) (Bjorneberg et al. 2008) compared to 800 to $1,200 \mathrm{~mm}$ at the other sites (table $3)$. In that watershed, drainage is a compan- ion practice to irrigation but is not essential for crop production. Furrow irrigation, also called surface irrigation, requires ditches at the bottom of every field to capture and convey irrigation runoff to the next field. These ditches are typically shallow $(<0.3 \mathrm{~m}$ deep) and do not capture any subsurface flow. They transport water to drains/laterals that may be 1 to $2 \mathrm{~m}$ deep. This surface-drained system does contribute to increased environmental impacts because the ditches and laterals convey water, nutrients, and sediment to the streams (Brown et al. 1974). In addition, infiltration during irrigation events has produced perched water tables above the basalt, which cause excessively wet ground (Brown et al. 1974; Bjorneberg et al. 2008). This has been addressed by excavating large $(1.3 \times 2.3 \mathrm{~m})$ drainage tunnels into the basalt layer underlying the soil profile. Excavation continued until a water carrying fracture through the basalt was intercepted, which effectively lowered these perched water tables by draining them into the Upper Snake Rock (Carter et al. 1971; Bjorneberg et al. 2008; Lentz et al. 2018). Irrigation is also present at other sites (e.g., Beasley), but not as heavily as in Upper Snake Rock, and it can be ignored.

Watersheds artificially drained with subsurface systems include the Walnut Creek, South Fork of the Iowa River, Cedar Creek, and Upper Big Walnut Creek watersheds. In the South Fork of the Iowa River and Walnut Creek watersheds, subsurface outflow dominates streamflow (Tomer et al. 2003). In Walnut Creek, almost $75 \%$ of the land area within the watershed is subsurface drained, concentrated in the upper portion of the watershed (Hatfield et al. 1999). Subsurface drainage has enabled the productivity of the soils to be realized but also led to substantial $\mathrm{NO}_{3}-\mathrm{N}$ loss (Karlen et al. 2008). Nitrate leaching through the subsurface drains has been recognized as a key management challenge in the watershed (Tomer et al. 2008). Nitrate-N concentrations in streams of the South Fork of the Iowa River watershed are so strongly dependent on base flow that they can be used as a surrogate for subsurface discharge (Tomer et al. 2008). Surface drainage of glacial depressions, a.k.a. prairie potholes, also exist in these two watersheds, with an inlet bringing surface water to a subsurface drain. In some of these watersheds, almost all $(\geq 90 \%)$ cropland is artificially drained (table 3). In others, topographic conditions require artificial drainage in most but not all 


\section{Figure 1}

Conservation Effects Assessment Project (CEAP) Watershed Assessment Studies sites used for the evaluation of the USDA Natural Resources Conservation Service proposed Soil Vulnerability Index for artificially drained cropland.

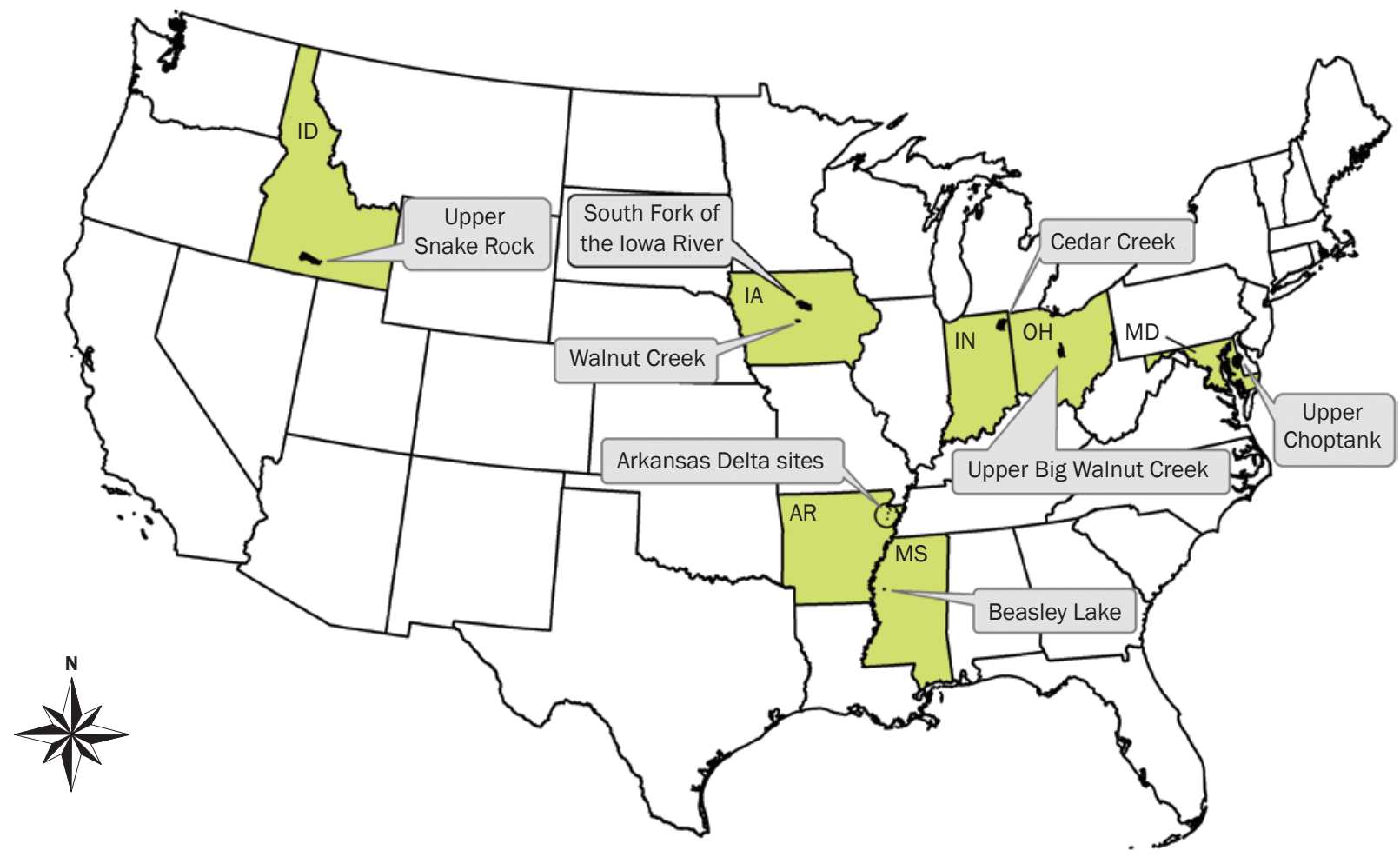

cropland (e.g., Cedar Creek watershed and Upper Big Walnut Creek watershed).

SVI Model Description. Thompson et al. (2020) give a full description of the SVI model (tables 1 and 2), which was based on the theoretical framework included in the CEAP cropland report (USDA NRCS 2012). The runoff component of the SVI was based on simulated erosion and sediment losses (Thompson et al. 2020). Indirectly, the index addresses the risk of soil degradation and of deterioration of receiving waters caused by the adsorbed nutrients removed and transported off the field with soil particles. The dominant pathway for $\mathrm{N}$ is leaching via either percolation, subsurface drains, or deep ditches. The leaching component of the $\mathrm{SVI}$ is an indicator of the risk of $\mathrm{NO}_{3}-\mathrm{N}$ loss, as well as some dissolved $\mathrm{P}$ loss via drainage ditches or subsurface drains, since those can be a significant pathway for dissolved $\mathrm{P}$ (Pease et al. 2018).

For artificially drained cropland, the leaching component of the SVI was calculated as indicated in table 2, including using the hydrologic soil group in undrained conditions in case of dual hydrologic soil group classification, and increasing the resulting vulnerability by two classes to reflect the presence of artificial drainage. The SVI does not differentiate subsurface from surface artificial drainage. In some of these watersheds, artificial drainage was not ubiquitous, but no drainage map was available to identify where ditches or subsurface drains were present. Therefore, two maps were developed: one that assumed artificial drainage on all cropland, and one that assumed there was none.

For each watershed, the SVI was calculated using the SSURGO soil map obtained from the web soil survey (Soil Survey Staff 2018). The associated SSURGO database provided the necessary soil properties: organic carbon (C) content, hydrologic soil group, rock content, and erodibility factor (K-factor) of the corresponding soil type. In the NRCS definition of the SVI, the slope value is the representative slope for each soil map unit. However, Chan et al. (2017) concluded that using a digital elevation model (DEM) derived slope produced results more consistent with observations of soil degradation. Based on these results, the SVI was calculated for each cell of a DEM raster, either obtained from the US Geological Survey (http://viewer.nationalmap.gov/launch/) or from the corresponding state (e.g., Light Detection and Ranging [LiDAR] data). Lohani et al. (2020) discussed different DEM resolution and concluded that the optimal resolution depended on the objectives of the analysis. For the purpose of this evaluation, a $10 \mathrm{~m}$ DEM resolution was determined to be a good balance between properly identifying relevant slopes without emphasizing noncropped ditches. A cell slope was calculated based on $10 \mathrm{~m}$ DEM cell elevation using the slope function in the ArcGIS Spatial Analyst tool (Esri, Redlands, California), which uses bilinear resampling. In selecting the hydrologic soil group and K-factor for complex soil map units, the aggregation method of "dominant condition" was chosen, which assigned the dominant hydrologic soil group and $\mathrm{K}$-factor.

The SVI risk for runoff and leaching was calculated and mapped based on the categorization table proposed by NRCS (tables 1 and 2). The leaching component of the SVI treats organic soils separately, assigning a high risk of leaching to organic soils, independently of any other consideration. Organic soil characterization was based on 
Table 3

Overview of the eight watersheds (from east to west) used for the evaluation of the Soil Vulnerability Index in a drained cropland context.

\begin{tabular}{|c|c|c|c|c|c|c|c|}
\hline Watershed & Size (ha) & $\begin{array}{l}\text { Average } \\
\text { annual } \\
\text { rainfall } \\
(\mathrm{mm})\end{array}$ & $\begin{array}{l}\text { Drainage } \\
\text { type }\end{array}$ & $\begin{array}{l}\text { Cropland } \\
(\%)\end{array}$ & $\begin{array}{l}\text { Cropland } \\
\text { artificially } \\
\text { drained (\%) }\end{array}$ & $\begin{array}{l}\text { Dominant soil } \\
\text { hydrologic groups } \\
\text { drained/undrained }\end{array}$ & References \\
\hline $\begin{array}{l}\text { Upper Big Walnut } \\
\text { Creek, Ohio }\end{array}$ & 47,200 & 1,023 & $\begin{array}{l}\text { Surface and } \\
\text { subsurface }\end{array}$ & 44 & 75 & $C / D$ & $\begin{array}{l}\text { King et al. } \\
(2008,2016)\end{array}$ \\
\hline $\begin{array}{l}\text { Arkansas Delta } \\
\text { sites }\end{array}$ & 7 to 30 & 1,224 & Surface & 100 & 100 & $C / D$ and $D$ & $\begin{array}{l}\text { Aryal et al. } \\
(2018)\end{array}$ \\
\hline $\begin{array}{l}\text { Beasley Lake, } \\
\text { Mississippi }\end{array}$ & 600 & 1,222 & Surface & 71 & 100 & C and D & $\begin{array}{l}\text { Yasarer et al. } \\
\text { (2020); Lizotte } \\
\text { et al. (2017) }\end{array}$ \\
\hline $\begin{array}{l}\text { Upper Snake } \\
\text { Rock, Idaho }\end{array}$ & 113,600 & 270 & $\begin{array}{l}\text { Surface and } \\
\text { subsurface }\end{array}$ & 76 & 100 & $C$ & $\begin{array}{l}\text { Bjorneberg et } \\
\text { al. (2008) }\end{array}$ \\
\hline
\end{tabular}

Note: Percentage cropland artificially drained considers any field with at least one artificial drainage feature as artificially drained.

\section{Table 4}

Slope distribution and fraction of cropland in test watersheds, based on a $10 \mathrm{~m}$ digital elevation model.

\begin{tabular}{|c|c|c|c|}
\hline \multirow[b]{2}{*}{ Watershed } & \multicolumn{3}{|c|}{ Watershed area (\%) } \\
\hline & $<\mathbf{2} \%$ slope & $<3 \%$ slope & $<4 \%$ slope \\
\hline Upper Choptank & 67 & 71 & 82 \\
\hline Upper Big Walnut Creek & 49 & 67 & 78 \\
\hline Cedar Creek & 38 & 56 & 69 \\
\hline Arkansas Delta sites & 100 & 100 & 100 \\
\hline Beasley Lake & 83 & 91 & 95 \\
\hline South Fork of the lowa River & 49 & 69 & 80 \\
\hline Walnut Creek & 49 & 70 & 83 \\
\hline Upper Snake Rock & 58 & 77 & 86 \\
\hline
\end{tabular}

the SSURGO definition for histosols and histic surface epipedons.

The SVI was developed for cropland (USDA NRCS 2012), which we defined as land associated with row crop agriculture, and identified using crop data layers (USDA NASS 2016). In most watersheds, crops included corn (Zea mays L.), soybeans (Glycine max [L.] Merr.), wheat (Triticum aestivum L.)/double crop soybeans, and spring or winter wheat. In others, there were additional crops. In Upper Snake Rock watershed,for example, crops grown included corn, barley (Hordeum vulgare L.), spring wheat, winter wheat, oats (Avena sativa L.), sugar beets
(Beta vulgaris L.), dry beans (Phaseolus vulgaris L.), potatoes (Solanum tuberosum L.), onions (Allium cepa L.), peas (Pisum sativum L.), fallow/idle cropland, triticale (Triticosecale), carrots (Daucus carota L.), and double crop barley/corn.

Evaluation of the SVI. The SVI is an interpretation of some soil properties (i.e., slope, rock content, K-factor, and hydrologic soil group information from each map unit) and is difficult to test against measured runoff, sediment, or nutrient data because of the short duration of the monitoring period and the additional factors that influence transport (weather and management).Thus, rather than evaluating the SVI against measured data, we evaluated whether SVI results were consistent with the processes that take place on the landscape, using the accumulated experience of the coauthors of this paper in their respective watershed. Questions were sent to them prior to a conference call. The goal of these conversations was to identify where the SVI worked well or not, and to identify the factors that caused inconsistencies between SVI classification and the known vulnerability. The SVI was evaluated at field scale for two sites: the Arkansas Delta site because it consists of a set of individual fields, and the Beasley Lake watershed because it is small enough that the scientists had good knowledge of the individual fields. Questions for field scale evaluation were the following:

1. Was SVI vulnerability consistent with the experience of land managers in these fields?

2. Was the SVI useful to differentiate field or subfield areas with higher vulnerability to runoff and leaching?

At watershed scales, questions asked were the following:

1. Was the SVI useful to identify areas of higher vulnerability to runoff and leaching?

2. Were the areas of higher vulnerability more challenging in terms of cropland management? Did the SVI relate to the issues of soil and nutrient loss in the watershed? 
3. If SVI vulnerability was uniform across a watershed, did all the fields behave in a similar way?

The coauthors of this paper had expert knowledge of landscape hydrologic processes in the watersheds in which they conducted research. They had extensively investigated their own watersheds prior to this analysis. Comparison of landscape processes to those considered in the SVI led to the identification of factors that could improve the accuracy and relevance of the SVI if incorporated into its calculation. The results below present a synthesis of these discussions, grouped by issue related to the use of the SVI at field and watershed scales.

\section{Results and Discussion}

Field-Scale Evaluation of the SVI. At the Arkansas Delta site, SVI vulnerability to runoff was either low or moderate depending on the hydrologic soil group because all the slopes were $<0.5 \%$ (table 5 , figure 2 ). SVI vulnerability to leaching was either moderately high or high once artificial drainage was considered (table 6). However, given the low permeability of these soils, the low slopes, and the long slope lengths for subsurface flow (Aryal et al. 2018), first principles of physics imply that subsurface lateral water movement is rather slow. Thus, the surface ditches capture mostly surface runoff, and increasing the SVI class for leaching potential by two classes, owing to the presence of artificial drainage, is misleading. Surface runoff is dominant, not leaching. A similar assessment was made in the Beasley Lake watershed. Soils in the hydrologic soil group $\mathrm{D}$ or C caused the SVI leaching component to be either low or moderate when artificial drainage was not considered, but moderately high or high once it was taken into account (tables 5 and 6, figure 2). A low to moderate leaching risk seemed more accurate than moderately high or high even when artificially drained because of the use of surface drainage combined with low percolation.

At the Arkansas Delta site, the SVI ratings for the Manila and Marked Tree fields were inconsistent with producers' choice of crops. The SVI rated both fields high for leaching. Yet the crops selected by the producer in these two fields reflect a difference in leaching potential: cotton (Gossypium hirsutum L.) in the Manila field contrasted with rice (Oryza sativa L.) and soybean in the Marked Tree field. Water yield in the watersheds for each

\section{Table 5}

Distribution of the runoff component of the Soil Vulnerability Index (SVI) in the test watersheds.

\begin{tabular}{llllc}
\hline & \multicolumn{4}{l}{ SVI class (\%) } \\
\cline { 2 - 5 } Watershed & Low & Moderate & $\begin{array}{l}\text { Moderately } \\
\text { high }\end{array}$ & High \\
\hline Upper Choptank & 67 & 17 & 12 & 4 \\
Upper Big Walnut Creek & 17 & 42 & 31 & 10 \\
Cedar Creek & 22 & 23 & 30 & 24 \\
Arkansas Delta sites & 59 & 41 & 0 & 0 \\
Beasley Lake & 61 & 24 & 13 & 2 \\
South Fork of the lowa River & 38 & 37 & 17 & 8 \\
Walnut Creek & 39 & 38 & 19 & 4 \\
Upper Snake Rock & 50 & 14 & 31 & 5 \\
& & & &
\end{tabular}

field also supported producers' observations (i.e., surface discharge per unit area for similar rainfall was higher at Marked Tree than at Manila [Aryal and Reba 2017]). Higher natural soil drainage influenced the choice of the producer for a cotton crop in the Manila fields. Growing rice in a field with higher natural soil drainage would be very unlikely, owing to the challenge of retaining sufficient water on the surface of the field. Thus, the choice of a rice crop for the Marked Tree field is consistent with its lower natural drainage than the Manila field. Several factors may explain the discrepancy between the high SVI vulnerability to leaching for both fields and the differentiated perceived capacity of the soils to drain. The SVI leaching vulnerability is the same for both fields because the SVI uses the dominant hydrologic group in undrained conditions, which is D in both fields. However, the Marked Tree field has a dominant hydrologic group $\mathrm{D}$, while the dominant hydrologic group of the Manilla field is $\mathrm{C} / \mathrm{D}$, meaning $\mathrm{D}$ in undrained conditions (table 7). The remaining components of this complex soil are in the hydrologic soil groups A or C. Even though the combined $\mathrm{D}$ and $\mathrm{C} / \mathrm{D}$ hydrologic groups dominate in both fields, they comprise less of the field at Manilla (43\%) than at Marked Tree (60\%). In addition, a C/D soil may not behave the same as a D soil. Runoff and rainfall data from winter events (no crop growing) at the Manila field showed that the average value of back-calculated curve numbers was 82 , which is more consistent with a bare soil in the hydrologic soil groups B than D (table 8). In presence of complex soils, the field dominant characteristics (hydrologic group and erodibility) may not be representative, and combining the SVI with other indicators of runoff and permeability may be necessary to ensure consistency with the processes occurring in the field. NRCS has already addressed this issue by requiring calculation of the SVI for all the components of a complex soil (USDA NRCS 2018). Finally, land leveling, which is common in this region, has the potential to expose subsurface layers and complicate the use of an index based on soil survey information. Field-scale application of a tool that relies on soil information derived at a larger scale may require additional sampling of soils in the field and determination of their characteristics. However, this goes against the SVI stated goal of being a quick assessment tool.

Watershed-Scale Evaluation of the SVI. Tables 5 and 6 show the distributions of the runoff and leaching components of the SVI for the cropland of these watersheds, respectively. Because artificial drainage results in only moderately high or high vulnerability, only these two vulnerability classes of the leaching component are included. In the following sections, we discuss the issues raised during the evaluation of the SVI at this scale: inconsistent soil maps across county lines, the treatment of organic soils, the differentiation of high soil vulnerability to leaching caused by highly permeable soils versus artificial drainage, the differences in leaching risk between surface and subsurface drainage, the consequences of a highly manipulated hydrology as in Upper Snake Rock, and the role of rainfall erosivity.

Inconsistent Soil Maps across County Lines. The two leaching maps for the Upper Big Walnut Creek watershed (figure 3) illustrate soil surveys that are not consistent from one county to another. The SSURGO soil surveys for the different counties were completed at different times, and a distinct demarcation can be observed in the hydrologic soil group classification. In particular, two soil map units had the same name 


\section{Figure 2}

Vulnerabilities to runoff, leaching, and leaching under artificial drainage as classified by the Soil Vulnerability Index (SVI) at surface drained sites: (a, d, h, k) SVI runoff component, (b, e, i, l) SVI leaching component when artificial drainage is not considered, and (c, f, j, m) SVI leaching component when artificial drainage is considered. (g) Map for the Upper Choptank watershed differentiates cropland with mineral and organic soils.

\section{Arkansas Delta sites}

(a)

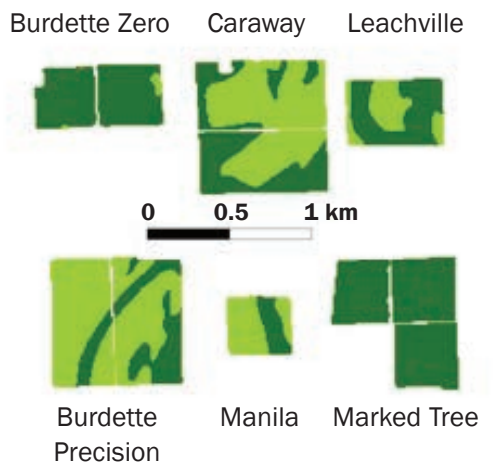

(b)
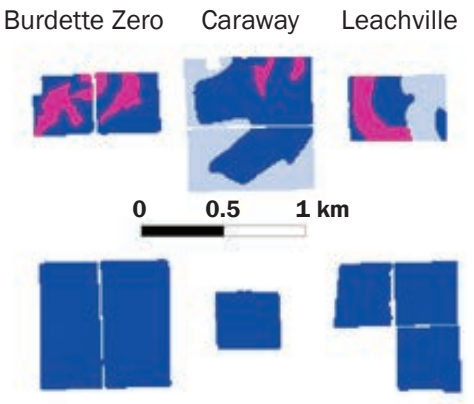

Burdette Precision (c)

\section{Beasley Lake watershed}

(d)
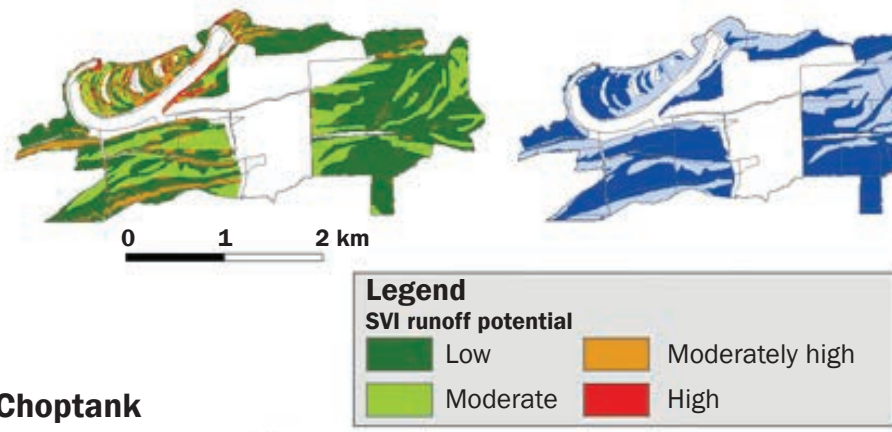

Upper Choptank
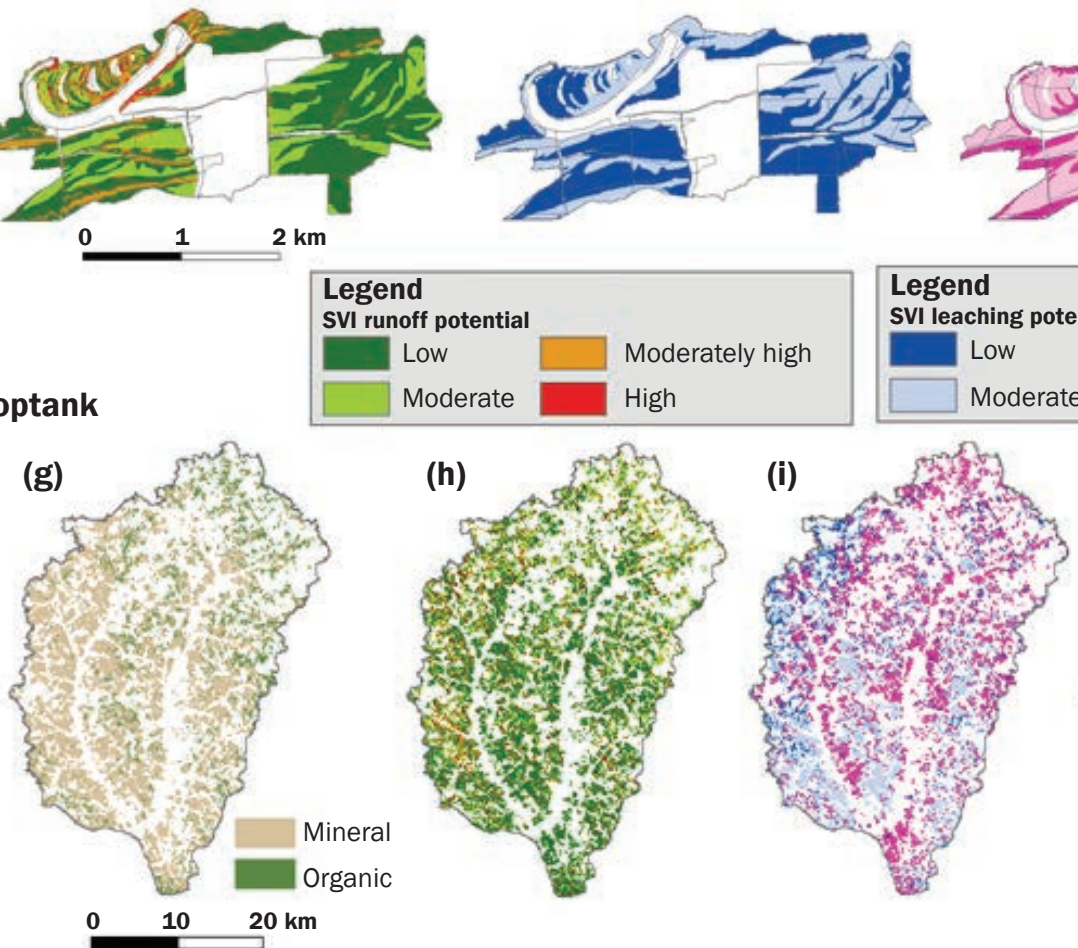

(f)
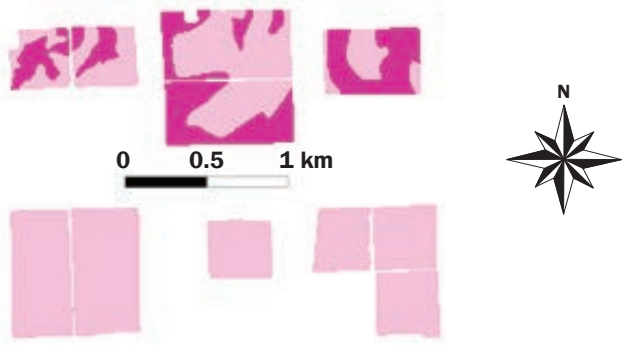

Manila Marked Tree
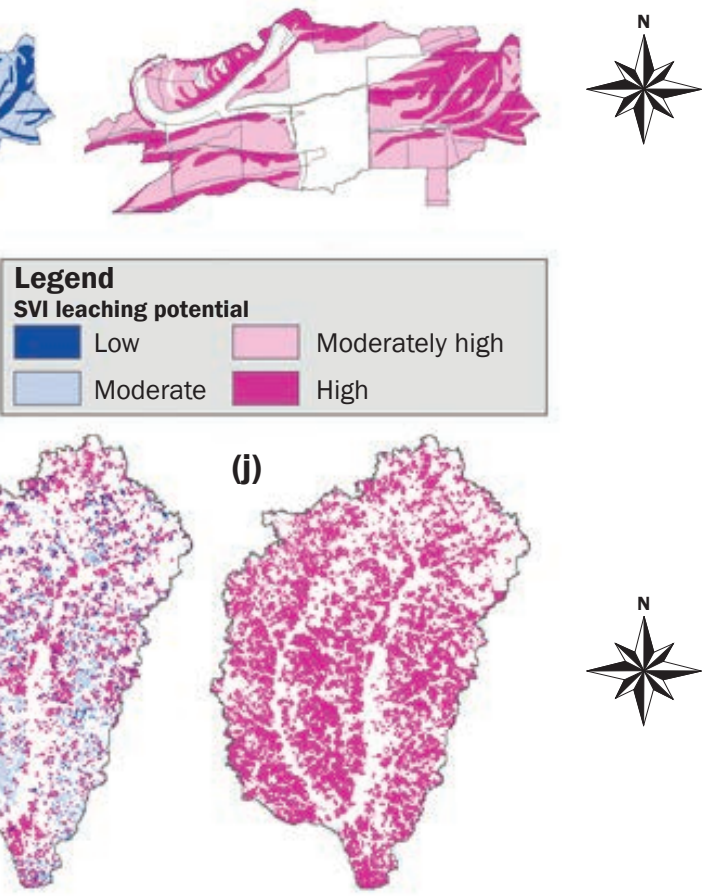

Upper Snake Rock

(k)

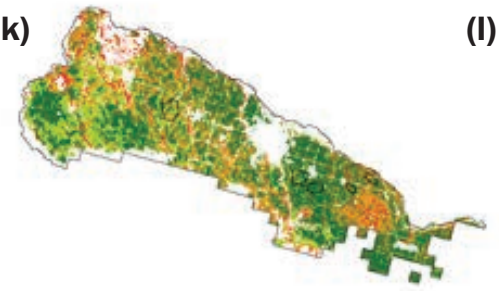

(I)

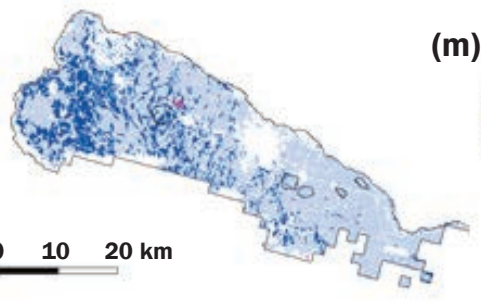

(m)

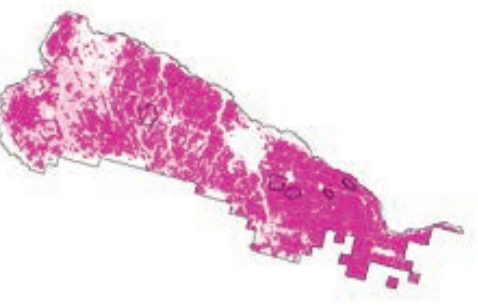

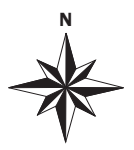


Table 6

Distribution of the leaching component of the Soil Vulnerability Index (SVI) for cropland in the test watersheds assuming all crop fields are artificially drained.

\begin{tabular}{lll}
\hline & SVI class (\%) & \\
\cline { 2 - 3 } Watershed & Moderately high & High \\
\hline Upper Choptank & 11 & 89 \\
Upper Big Walnut Creek & 88 & 12 \\
Cedar Creek & 80 & 20 \\
Arkansas Delta sites & 79 & 21 \\
Beasley Lake & 58 & 42 \\
South Fork of the lowa River & 57 & 43 \\
Walnut Creek & 61 & 39 \\
Upper Snake Rock & 26 & 74
\end{tabular}

Table 7

Characteristics of the main complex soils underlying the Manila and Burdette fields at the Arkansas Delta sites.

\begin{tabular}{|c|c|c|c|}
\hline Soil characteristics & $\begin{array}{l}\text { Dominant } \\
\text { component }\end{array}$ & $\begin{array}{l}\text { Second } \\
\text { component }\end{array}$ & $\begin{array}{l}\text { Third } \\
\text { component }\end{array}$ \\
\hline \multicolumn{4}{|c|}{ Routon-Dundee-Crevasse complex (Manila fields) } \\
\hline Component name & Routon & Dundee & Crevasse \\
\hline Map unit (\%) & 35 & 30 & 20 \\
\hline Hydrologic soil group & $C / D$ & C & A \\
\hline K-factor & 0.49 & 0.43 & 0.05 \\
\hline Slope (\%) & $<2$ & $<2$ & $<2$ \\
\hline SVI runoff component & Moderate & Low & Low \\
\hline SVI leaching component & Moderately high & High & High \\
\hline $\begin{array}{l}\text { Theoretical curve number } \\
\text { for fallow land, drained }\end{array}$ & 88 to 91 & 88 to 91 & 74 to 77 \\
\hline \multicolumn{4}{|c|}{ Sharkey-Crevasse complex (Burdette fields) } \\
\hline Component name & Sharkey & Crevasse & - \\
\hline Map unit (\%) & 50 & 30 & - \\
\hline Hydrologic soil group & $\mathrm{D}$ & A & - \\
\hline K-factor & 0.28 & 0.05 & - \\
\hline Slope (\%) & $<2$ & $<2$ & - \\
\hline SVI runoff component & Moderate & Low & - \\
\hline SVI leaching component & Moderately high & High & - \\
\hline $\begin{array}{l}\text { Theoretical curve number } \\
\text { for fallow land, drained }\end{array}$ & 90 to 94 & 74 to 77 & - \\
\hline \multicolumn{4}{|c|}{ Sharkey-Steele complex (Manila, Burdette, and Marked Tree fields) } \\
\hline Component name & Sharkey & Steele & - \\
\hline Map unit (\%) & 60 & 30 & - \\
\hline Hydrologic soil group & $\mathrm{D}$ & A & - \\
\hline K-factor & 0.24 & 0.05 & - \\
\hline Slope (\%) & $<2$ & $<2$ & - \\
\hline SVI runoff component & Low & Low & - \\
\hline SVI leaching component & Moderately high & High & - \\
\hline $\begin{array}{l}\text { Theoretical curve number for } \\
\text { fallow land, drained }\end{array}$ & 90 to 94 & 74 to 77 & - \\
\hline
\end{tabular}

Note: SVI = Soil Vulnerability Index.
(Centerburg silt loam) in Morrow County in the north and Delaware County, but were characterized as hydrologic soil group $\mathrm{C}$ for undrained condition in Morrow County and $\mathrm{D}$ in Delaware County. These differences in hydrologic soil group affected the SVI estimates of vulnerability to leaching. We expect that NRCS will address these differences during future revisions of the soil surveys, but SVI users should be aware of the potential for these discrepancies.

Treatment of Organic Soils. Approximately $18 \%$ of the Upper Choptank cropland soils are organic soils (figure 2). These soils can have $>50 \%$ organic matter in the top soil horizon, which varies in thickness from 5 to $20 \mathrm{~cm}$. For the most part, those are hydric soils, and while most of these organic soils underlie wetlands, some were drained and are productive cropland. Artificially drained or not, these soils result in high SVI vulnerability to leaching. Yet, even when drained, hydric soils tend to remain wet during wet years because of properties such as high clay content and location in low lying areas of the landscape. Crops grow poorly during wet years on these soils, in spite of artificial drainage. For example, when wet spring conditions delay planting, producers switch to soybeans because of their shorter growing season. Thus, the high leaching rating conferred by the SVI to these soils, which is equivalent to the leaching rating for welldrained soils, is exaggerated.

Without artificial drainage, the hydric soils in the poorly drained upland areas increased denitrification and herbicide degradation, resulting in improved water quality of surface runoff (Hively et al. 2011). With artificial drainage, these wetland ecosystem services may be reduced, thus affecting the quality of the surface and subsurface runoff. Hence, artificial drainage of these depressions does have a negative impact on overall losses from the field, but through surface runoff, not leaching. However, presence of artificial drainage affects the leaching component of the SVI but leaves the runoff component untouched.

Artificial Drainage versus Permeable Soils. In artificially drained conditions, the risk of leaching was either moderately high or high because artificial drainage raises the risk by two classes, effectively lumping four potential risk classes into only two (table 2). In order to differentiate the leaching risks caused by high permeability of soils from that caused by artificial drainage, we ran the leaching 


\section{Table 8}

Calculated curve number for 11 winter events measured at the Manila control field.

\begin{tabular}{lclll}
\hline Event date & $\begin{array}{l}\text { Rainfall } \\
(\mathbf{m m})\end{array}$ & $\begin{array}{l}\text { Observed } \\
\text { discharge } \\
(\mathbf{m m})\end{array}$ & $\begin{array}{l}\text { Potential maximum } \\
\text { retention after runoff } \\
\text { begins } \mathbf{( S )}(\mathbf{m m})\end{array}$ & $\begin{array}{l}\text { Curve } \\
\text { number }\end{array}$ \\
\hline Feb. 21, 2015 & 44 & 20.8 & 1.2 & 89 \\
Mar. 14, 2015 & 45 & 23.1 & 1.1 & 90 \\
Apr. 14, 2015 & 57 & 29.7 & 1.3 & 88 \\
Nov. 29, 2015 & 106 & 43.9 & 3.5 & 74 \\
Nov. 28, 2016 & 48 & 3.2 & 5.1 & 66 \\
Dec. 5, 2016 & 7 & 0.2 & 0.9 & 92 \\
Dec. 17, 2016 & 28 & 5.4 & 1.9 & 84 \\
Mar. 27, 2017 & 18 & 4.8 & 0.9 & 92 \\
Apr. 22, 2017 & 28 & 1.0 & 3.5 & 74 \\
Apr. 26, 2017 & 41 & 4.4 & 3.6 & 73 \\
Apr. 29, 2017 & 102 & 45.7 & 3.1 & 77 \\
& & & &
\end{tabular}

component of the SVI twice: once assuming no artificial drainage, and once assuming that all cropland was artificially drained (table 6).

A moderately high or a high leaching risk is predicted by the SVI in one of the following conditions: the land is artificially drained, soils are organic, soils are in the hydrologic soil group A or soil group B, slope $\leq 12 \%$, and erodibility $<0.24$. Greater soil permeability increases the risk of $\mathrm{NO}_{3}$ leaching to groundwater; artificial drainage increases the risk of $\mathrm{NO}_{3}$ transport to streams or lakes via drains or ditches. The two processes affect different water resources, have different flow paths, and should be addressed separately. Thus, it is important to distinguish the two sets of conditions when they both co-exist, as was the case in the Upper Choptank and in some of the Arkansas Delta sites. At these two sites, all the SVI leaching risks were either moderately high or high under artificially drained conditions. Yet, the SVI leaching risks without artificial drainage ranged from low to high (figure 2), showing the location of high permeability soils, which pose risks to groundwater resources. Calculating the SVI with and without artificial drainage is necessary for correct interpretation of the results. For the Beasley Lake (figure 2), and Upper Big Walnut Creek, Cedar Creek, Walnut Creek, and South Fork of the Iowa River (figure 3) watersheds, the SVI leaching risks without artificial drainage were low or moderate because soils were in hydrologic soil groups $\mathrm{C}$ or $\mathrm{D}$, or because slopes were high enough that surface runoff was the primary flow path. Calculating the SVI with and without artificial drainage conditions showed the increase in vulnerability caused by artificial drainage. NRCS has already addressed this issue by splitting the leaching component into two: the leaching component, which describes vulnerability to leaching without considering artificial drainage, and the managed leaching component, which does consider artificial drainage (USDA NRCS 2018).

The situation is slightly different in the Upper Snake Rock watershed (figure 2), for which artificial drainage is a necessity because the amount of irrigation water diverted into the canals does not exactly match the irrigation requirements and some water drains back to the river along with runoff from surface irrigated fields (Bjorneberg et al. 2008). If irrigation methods should switch completely from furrow to sprinkler irrigation, surface drainage may not be necessary because sprinkler irrigation has higher irrigation efficiency $(80 \%)$ than furrow irrigation (60\%; James 1988). In this watershed, determination of the likelihood of artificial drainage does have to take irrigation method into account, which the SVI does not.

Surface versus Subsurface Artificial Drainage. The SVI considers artificial drainage as a flag without any consideration of the type of drainage. In general, the SVI vulnerability to leaching was appropriate for subsurface drainage systems. In the Upper Big Walnut Creek watershed, all the cropland was either in the low or moderate leaching risk class when artificial drainage was not considered, because of the C and D soil hydrologic groups (figure 3). Artificial drainage raised the SVI risk of nutrient losses by leaching to moderately high or high (figure 3, table 6). The high SVI vulnerability to leaching is consistent with the fact that most of the subsurface drainage in this watershed occurs for 9 to 10 months in the year, may drop in July to August as crops mature and water table draws down, and starts to flow again in October (Williams et al. 2015). In the South Fork of the Iowa River and Walnut Creek watersheds, the SVI captured the vulnerability of these soils to leaching very well. The SVI leaching index reflects the importance of this issue as it describes the dominant low vulnerability to leaching in the watershed without artificial drainage, which increases to moderately high or high after accounting for the drainage system (figure 3). On the other hand, the vulnerability to runoff predicted by the SVI was initially considered too high because there is no allowance for the fact that subsurface drainage reduces surface runoff volumes and peak runoff rates because of greater available water holding capacity (Skaggs et al. 1994). However, surface management practices are useful to control erosion at the drainage outlet so that the outflow does not erode the bank of the receiving stream. Leaving the SVI runoff vulnerability untouched highlights the need for such practices.

In the Cedar Creek watershed, SVI classification of leaching risks resulted in more than $50 \%$ of the land in the low vulnerability category and about $45 \%$ of the land in the moderate risk class when artificial drainage was not considered (figure 3). However, $80 \%$ of the cropland is subsurface-drained (Heathman et al. 2009). As a result, the entire watershed was classified in the high and moderately high vulnerability class for leaching (figure 3, table 6). This led to a high risk for both runoff and leaching for $>50 \%$ of the crop fields in the watershed. This reflects accurately the conditions experienced by producers: high vulnerability to erosion and gully formation, and high vulnerability to nutrient loss through leaching (Smith et al. 2008).

In case of artificial surface drainage, the SVI vulnerability to runoff and leaching were not appropriate. Actual leaching risks were lower than indicated by the SVI, and runoff risks were higher than predicted, as shown in the following examples. In the Upper Choptank watershed, surface ditches drain numerous surface depressions, which would be wetlands if not artificially drained (Fenstermacher et al. 2014; McCarty et al. 2008). These soils cannot be used to grow crops unless they are artificially drained. In comparison to subsurface drains, surface ditches are more likely 


\section{Figure 3}

Vulnerabilities to runoff, leaching, and leaching under artificial drainage as classified by the Soil Vulnerability Index (SVI) in watersheds characterized by the presence of subsurface drains: (a, d, g, j) SVI runoff component, (b, e, h, k) SVI leaching component when artificial drainage is not considered, and (c, f, i, l) SVI leaching component when artificial drainage is considered.

\section{Upper Big Walnut Creek}

(a)

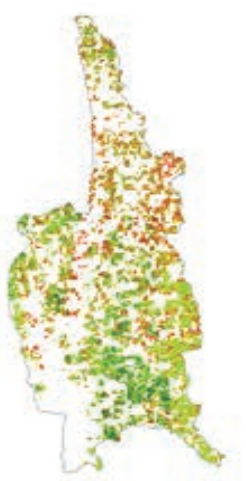

Cedar Creek

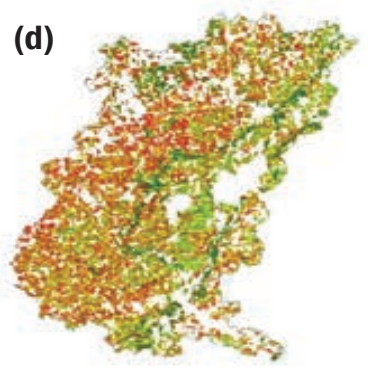

(b)

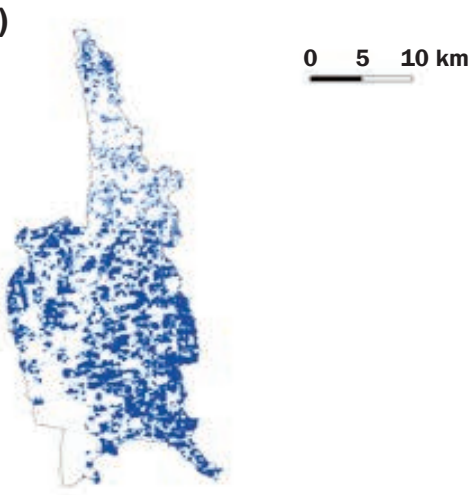

(c)
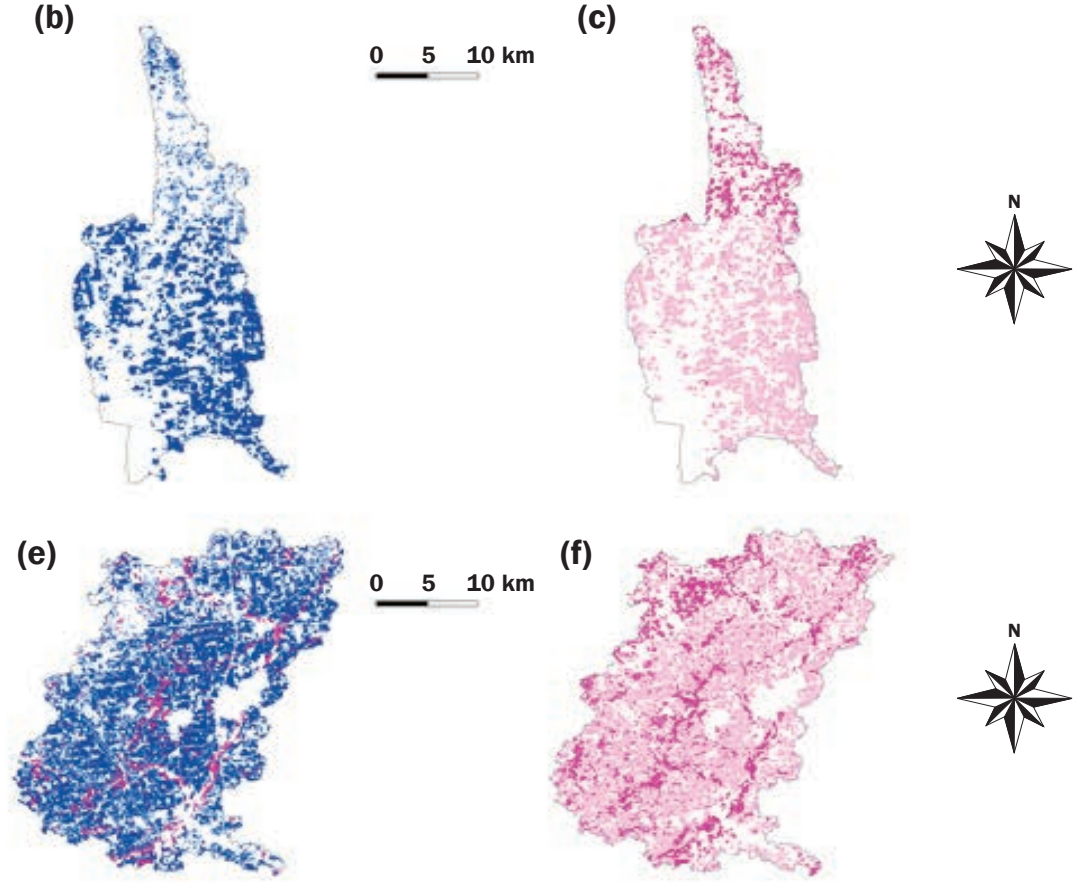
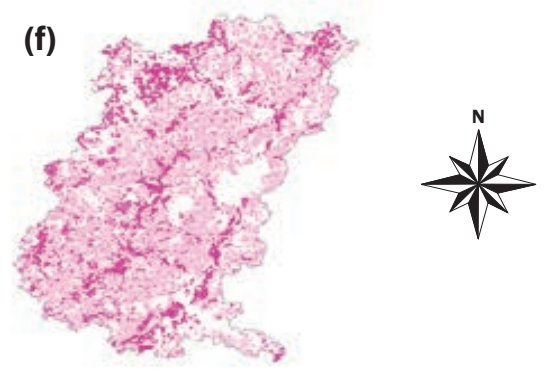

\section{South Fork of lowa River}

(g)

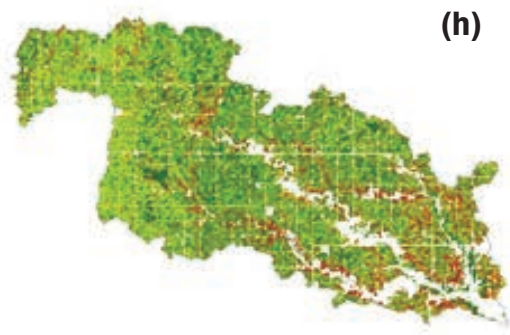

Walnut Creek

(j)

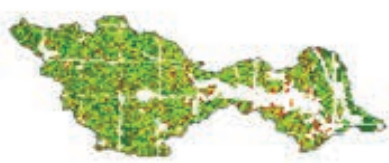

(k)

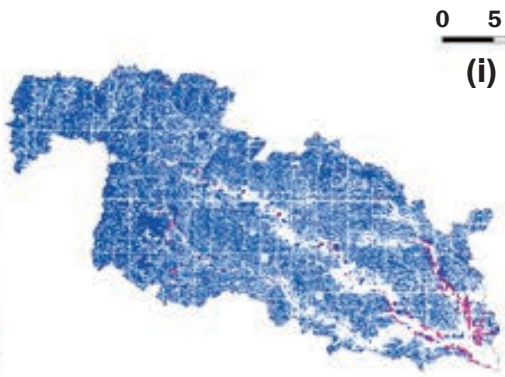

$10 \mathrm{~km}$

(i)
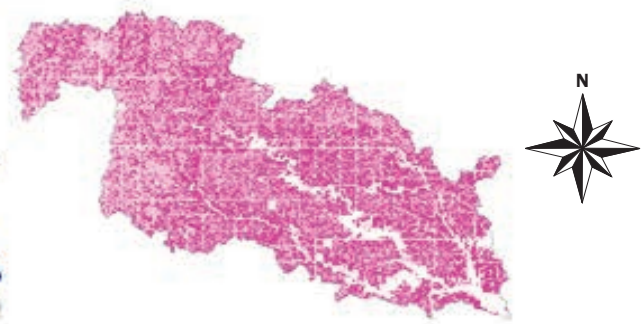

0

\section{(I)}

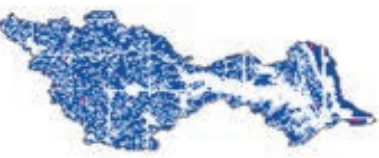

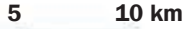
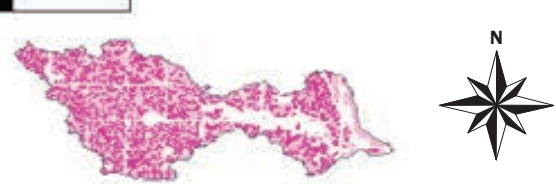

\begin{tabular}{|c|c|}
\hline $\begin{array}{l}\text { Legend } \\
\text { SVI runoff potential } \\
\text { Low }\end{array}$ & Moderately high \\
\hline Moderate & High \\
\hline
\end{tabular}

\begin{tabular}{|l|l|}
\hline \begin{tabular}{l} 
Legend \\
SVI leaching potential \\
\hline Low \\
\hline Moderate \\
\hline
\end{tabular} Moderately high \\
\hline
\end{tabular}


to transport sediment from the fields and be subject to streambank degradation without proper banks maintenance. Draining surface depressions actually increases the total volume of runoff to the streams (Lee et al. 2016). The SVI underestimated the vulnerability to runoff in the watershed because it did not take into account the runoff drained from these depressions. Depression areas, characterized by slope $<2 \%$, were all in a low vulnerability class for runoff.Yet they do contribute to runoff, sediment, and nutrient stream loads because of the surface ditches (Lee et al. 2016). On the other hand, the SVI predicted high leaching vulnerability owing to artificial drainage. Yet these depressions are drained via surface rather than leaching processes. The moderately high or high SVI vulnerability for leaching from these drained depressions reflected the risks to stream water quality, but attributed it to leaching processes rather than runoff processes. That could be acceptable if the purpose of the SVI was to determine an overall risk of farming in terms of water quality, i.e., if the runoff and leaching components of the SVI were grouped together to provide an overall risk assessment. However, if the runoff and leaching components are interpreted separately to guide the type of conservation needs on that land, the low runoff risk and high leaching risk estimated by the SVI could mislead conservation planners.

In Iowa (Walnut Creek and South Fork of the Iowa River watersheds), the prairie potholes also contribute a substantial proportion of runoff. Saleh et al. (2007) estimated that pothole area occupied $10 \%$ of the watershed, but $57 \%$ of the total surface runoff directly flowed into potholes. Without drainage, these potholes would retain water from poorly drained areas for long periods (Saleh et al. 2007). With artificial drainage through surface intakes and underground pipes, these areas contribute not only runoff but also $\mathrm{NO}_{3}$, dissolved $\mathrm{P}$, and herbicides to the receiving streams (Tomer et al. 2010) because there is no time for herbicide degradation or denitrification. However, these depressions are not a source of sediment, as those settle out around the surface intake. Instead, streams, which are beyond the scope of the SVI, are the major sources of sediment - and an important source of total $\mathrm{P}$ (Tomer et al. 2010).

While the SVI runoff component correctly reflected the low risk for soil erosion from cropland in Walnut Creek and the South Fork of the Iowa River watersheds (low vulnerability to runoff), it underestimated the risk of $\mathrm{P}$ loss because it did not consider the pathway from potholes to the streams via surface inlets. The high ranking of the SVI leaching component could counterbalance this low classification as long as the two components are interpreted together. However, it would be misleading, as the $\mathrm{P}$ loss from drained potholes is primarily a surface runoff process with a subsurface delivery mechanism from the pothole to the stream rather than a leaching process through the soil and a subsurface drain.

Upper Snake Rock: A Special Case. In the Upper Snake Rock watershed, local water management complicated soil leaching potential vulnerability classification. When artificial drainage was not considered, the dominant leaching vulnerability in the region was moderate (figure 2), owing to most soils being in the hydrologic soil group C. When artificial drainage was considered, high vulnerability was dominant. While there is no subsurface drainage in the area, there is a lot of manipulation to collect surface and percolated water. Yet, the transport of sediment and sediment-bound nutrients in Upper Snake Rock is essentially a surface process, and the increase of the SVI leaching component by two classes because of this drainage was misleading, implying pollutant transport by leaching instead of surface processes. Generally, the leaching vulnerability without artificial drainage seemed to be the most representative of the region. On the other hand, the large tunnels that drain the perched water table caused by years of furrow irrigation do contribute to the transport of nutrients and agricultural chemical inputs to the stream (Lentz et al. 2018). Overall, the SVI was not very useful in this watershed because of the numerous modifications and complexity of the water conveyance system.

In addition, irrigation can have significant impacts on surface water quality and leaching. As seen in the Upper Snake Rock watershed, surface irrigation has caused significant leaching to the point of creating a manmade shallow aquifer. Irrigation may not be a concern in the Upper Mississippi and Ohio-Tennessee River basins where the SVI was originally developed but is present in many other cropland areas of the United States. Thus, along with artificial drainage, the SVI should consider whether irrigation is likely to increase leaching, which is a function of irrigation method, amount, and timing.

Role of Rainfall Erosivity. In the Upper Big Walnut Creek watershed, the SVI runoff potential overestimated the vulnerability to runoff. In intensively drained regions of Ohio, runoff remains very small or does not occur during most rainfall events (Pease et al. 2018). However, when significant runoff occurs, about two to three times each year, it is associated with high levels of sediment and nutrient loss (Pease et al. 2018). Vulnerability to runoff and erosion depends on rainfall intensity and amount (King et al. 2009, 2015), and in Ohio, those are relatively low as indicated by the rainfall runoff factor (R-factor) values ranging from 95 in the Northwest to 155 in the Southwest (USDA ARS 2013). Conversely, in the Beasley Lake watershed, the SVI appeared to underestimate inherent soil vulnerability to runoff. The low slopes $(<2 \%)$ resulted in a low or moderate vulnerability to runoff according to the SVI (figure 2, table 5). Despite very low slopes $(<2 \%)$ in this watershed and for most fields in the lower Mississippi Delta region (R-factor of 350), runoff-induced sediment losses are significant during the high winter and spring rainfall events (Cullum et al. 2010; Wren et al. 2019). The primary factors influencing soil erosion in this landscape include high intensity rainfall, low soil permeability and thus high runoff potential, and relatively low soil organic C. The SVI considers permeability through the hydrologic soil group, and organic $\mathrm{C}$ is indirectly represented, via the effect it has on soil erodibility (K-factor; Wischmeier and Smith 1978). Indeed, the K-factor is $>0.32$ for most of the cropland in this watershed. Low $\mathrm{C}$ content increases soil erodibility and the likelihood and amount of sediment and associated nutrient loss during high rainfall intensity events. However, the SVI does not consider rainfall intensity and the low slopes $(<2 \%)$ resulted in a low or moderate SVI vulnerability to runoff. Introducing some measure of rainfall intensity into the SVI is needed to improve predictions and avoid a false sense of low vulnerability to runoff processes. Given the focus on erosion and soil degradation, an appropriate method could be to use the R-factor.

Synthesis and Proposed Improvements. In this study, soil vulnerability to runoff from artificially drained land was either 
underestimated or appropriate. Conversely, vulnerability to leaching was either overestimated or appropriate. Reasons for each assessment were different and are summarized below, along with possibilities on how to address the discrepancies between SVI classification and our knowledge of these watersheds.

In cases of subsurface drains placed within or below the root zone to lower the water table, the consensus was that the SVI estimated the runoff and leaching risks accurately, including with the two-class vulnerability increase to accommodate artificial drainage impacts. In cases of surface artificial drainage of surface depressions or very flat land, with surface ditches or with surface inlets that bring the water to subsurface drains, the consensus was that the SVI underestimated the risk of runoff and overestimated the leaching risk. Reasons were that the runoff component of the SVI did not account for the surface runoff that otherwise accumulated in surface depressions. Surface artificial drainage results in increased surface runoff delivered to streams compared to what would have happened without artificial drainage. Surface drainage also affects leaching minimally because drainage ditches do not lower the water table significantly.

By treating all artificial drainage in the same way, the SVI implies that draining the soil profile with surface ditches surrounding or crossing the field is as effective at lowering the water table within the soil profile-and as risky in terms of $\mathrm{NO}_{3}$ transport-as subsurface drainage systems. In addition, it may confuse conservation planners using the SVI as to what processes are responsible for the risks. Surface drainage transports runoff and associated dissolved and particulate contaminants to receiving streams (Skaggs et al. 1994) while subsurface drainage systems increase the risk of $\mathrm{NO}_{3}-\mathrm{N}$ and dissolved $\mathrm{P}$ transport via subsurface water movement (Tomer et al. 2010; King et al. 2015; Williams et al. 2015). A possible SVI modification would be to differentiate surface from subsurface artificial drainage and increase the risk class of the runoff or leaching component, depending on what type of drainage is used.

Raising the leaching risk class by two levels also resulted in less differentiation of vulnerabilities to leaching in a given area. Distinguishing high vulnerabilities to leaching caused by inherent soil properties or the presence of artificial drainage is important in order to plan for appropriate practices. In case of field assessment, the farm operator or the conservationist is probably aware of the processes and conditions in that field. However, at watershed or regional scale, both conditions leading to high leaching vulnerabilities may be present but not distinguished by the SVI. For example, there may be cropland underlain by very permeable soils (hydrologic soil group A or B) next to very poorly drained soils (hydrologic soil group D) that require artificial drainage. The SVI classifies both sets of conditions as highly vulnerable to leaching, but each set requires different methods to address that vulnerability. NRCS has implemented what we did here: applying the leaching component of the SVI twiceonce in undrained conditions and once in artificially drained conditions (USDA NRCS 2018). The results differentiate the causes of vulnerability to leaching: highly permeable soils and artificial drainage.

Finally, this analysis highlights factors that affect vulnerability but are not represented in the SVI. At the watershed or regional scale, presence or absence of artificial drainage in each field is not necessarily available, requiring assumptions to be made. In this analysis, we assumed that all cropland was artificially drained. In the most recent version of the SVI, NRCS determines the need for artificial drainage based on NRCS drainage class (USDA NRCS 2018). Additional factors (e.g., shallow topsoil) may need to be considered. For example, poorly drained soils in northern Missouri are typically not artificially drained because the shallow top soil depth makes irrigation a requirement associated with artificial drainage, and marginal crop yields make investment in these practices more challenging. At field scale, limitations exist in the presence of a complex soil. Components of a complex soil can belong to different hydrologic soil groups and may have very different K-factors, which produce different estimates of the vulnerability of the field to runoff and leaching. Thus, SVI assessment for each component of that complex soil are necessary for full evaluation of the potential risks. Limitations exist at both scales when the hydrologic system is heavily manipulated.

The assessment of the SVI in Beasley Lake watershed highlighted the role of rainfall and rainfall intensity. The SVI was developed with data from the Upper Mississippi and OhioTennessee River basins, thus in a region where rainfall amounts and intensities vary but are within a more limited range: around 20 to 35 $\mathrm{mm} \mathrm{h}^{-1}$ for a one year, one hour storm in the SVI development region compared to 35 to $56 \mathrm{~mm} \mathrm{~h}^{-1}$ in Mississippi (Hershfield 1961). Given similar soil and topographic properties, a field is significantly more vulnerable to soil and nutrient loss by runoff in Mississippi than in Ohio because of the greater rainfall intensities that occur there. Vulnerability to runoff was considered too high in Ohio and too low in Mississippi, in part because of rainfall intensities. Incorporating some form of rainfall intensity into the SVI algorithm, possibly via the $\mathrm{R}$-factor, would eliminate this risk. In regions where irrigation is a frequent practice, the SVI should consider the impact of irrigation on leaching and surface water quality.

\section{Summary and Conclusions}

This analysis evaluated the applicability of the SVI tool in eight watersheds for which artificial drainage was a significant part of cropland management. Overall, the SVI was found to be a useful tool for field vulnerability assessment (for example prior to the development of a conservation plan), or for vulnerability quantification and mapping within a watershed or a region. The analysis specifically highlighted the following:

- Vulnerability to runoff and leaching was considered adequate for sites with subsurface drainage and with climate similar to what exists in the Upper Mississippi and Ohio-Tennessee River basins.

- In case of surface artificial drainage, vulnerability to runoff was considered underestimated and vulnerability to leaching was considered overestimated.

- In areas with rainfall intensities smaller or greater than those typically found in the Upper Mississippi and Ohio-Tennessee River basins, vulnerability to runoff was too high or too low, respectively.

- The SVI should consider the impacts of irrigation on surface water quality and drainage.

- At watershed or regional scale, the leaching component should be considered both with and without artificial drainage to distinguish the causes of the vulnerability (permeable soils or artificial drainage).

- At field scale, if complex soils underlie the field, or if land leveling exposes soil subsurface layers, determination of the exact soil components in the field is necessary to obtain accurate vulnerability classification. 


\section{Acknowledgements}

This research was funded through a 2015-2018 grant agreement 67-3A75-15-169 from USDA Natural Resources Conservation Service to Agricultural Research Service entitled "CEAP Watersheds Assessment Study and National Soil Survey Center Joint Multi Location Project: Evaluation and Improvement of the Soil Vulnerability Index."

\section{Disclaimer}

The findings and conclusions in this publication are those of the authors and should not be construed to represent any official USDA or US Government determination of policy.

\section{References}

Alexander, R.B., R.A. Smith, G.E. Schwarz, E.W. Boyer, J.V. Nolan, and J.W. Brakebill. 2008. Differences in phosphorus and nitrogen delivery to the Gulf of Mexico from the Mississippi River basin. Environment Sciences and Technology 42(3):822-830.

Aryal, N., and M.L. Reba. 2017.Transport and transformation of nutrients and sediment in two agricultural watersheds in northeast Arkansas. Agriculture, Ecosystems and Environment 236:30-42.

Aryal, N., M.L. Reba, N. Straitt, T.G. Teague, J. Bouldin, and S. Dabney. 2018. Impact of cover crop and season on nutrients and sediment in runoff water measured at the edge of fields in the Mississippi Delta of Arkansas. Journal of Soil and Water Conservation 73(1):24-34, doi:10.2489/jswc.73.1.24.

Bakhsh, A., J.L. Hatfield, R.S. Kanwar, L. Ma, and L.R. Ahuja. 2004. Simulating nitrate drainage losses from a Walnut Creek watershed field. Journal of Environmental Quality 33:114-123.

Bengtson, R.L., and C.E. Carter. 2004. The effect of subsurface drainage on water quality from soybeans. In Drainage VIII. St. Joseph, MI: American Society of Agricultural Engineers.

Bengtson, R.L., C.E. Carter, J.L. Fouss, L.M. Southwick, and G.H. Willis. 1995. Agricultural drainage and water quality in Mississippi Delta. Journal Irrigation and Drainage Engineering 121:292-295.

Bhattarai, R., P.K. Kalita, and M.K. Patel. 2009. Nutrient transport through a vegetative filter strip with subsurface drainage. Journal of Environmental Management 90(5):1868-1876.

Bjorneberg, D.L., D.T. Westermann, N.O. Nelson, and J.H. Kendrick. 2008. Conservation practice effectiveness in the irrigated Upper Snake River/Rock Creek watershed. Journal of Soil and Water Conservation 63(6):487-495, doi:10.2489/jswc.63.6.487.

Bosch, D.D., C.C. Truman, T.L. Potter, L.T. West, T.C. Strickland, and R.K. Hubbard. 2012. Tillage and slope position impact on field-scale hydrologic processes in the South Atlantic Coastal Plain. Agricultural Water Management 111:40-52.
Brown, M.J., D.L. Carter, and J.A. Bondurant. 1974. Sediment in irrigation and drainage waters and sediment inputs and outputs for two large tracts in southern Idaho. Journal of Environmental Quality 3(4):347-351.

Carter, D.L., J.A. Bondurant, and C.W. Robbins. 1971. Water soluble $\mathrm{NO}_{3}$-nitrogen, $\mathrm{PO}_{4}$-phosphorus, and total salt balances on a large irrigation tract. Soil Science Society of America Proceedings 35(2):331-335.

Chan, R., C. Baffaut, A.L. Thompson, and E.J. Sadler. 2017. Validating the Soil Vulnerability Index for a claypan watershed. CATENA 148(2):185-194.

Cullum, R.F., M.A. Locke, and S.S. Knight. 2010. Effects of conservation reserve program on runoff and lake water quality in an oxbow lake watershed. Journal of International Environmental Application and Science 5(3):318-328.

Duriancik, L.F., D.A. Bucks, J.P. Dobrowolski, T. Drewes, S.D. Eckles, L. Jolley, R.L. Kellogg, D. Lund, J.R. Makuch, M.P. O'Neill, C.A. Rewa, M.R. Walbridge, R. Parry, and M.A. Weltz. 2008. The first five years of the Conservation Effects Assessment Project. Journal of Soil and Water Conservation 63(6):185A-197A, doi:10.2489/jswc.63.6.185A.

Fausey, N.R., L.C. Brown, H.W. Belcher, and R.S. Kanwar. 1995. Drainage water quality in Great Lakes and Cornbelt states. Journal of Irrigation and Drainage Engineering 121(4):283-288.

Fenstermacher, D.E., M.C. Rabenhorst, M.W. Lang, G.W. McCarty, and B.A. Needelman. 2014. Distribution, morphometry, and land use of Delmarva Bays. Wetlands 34(6):1219-1228.

Green, C.H., M.D. Tomer, M. Di Luzio, and J.G. Arnold. 2006. Hydrologic evaluation of the Soil and Water Assessment Tool for a large tile-drained watershed in Iowa. Transactions of the ASABE 49(2):413-422.

Hatfield, J.L., D.B. Jaynes, M.R. Burkart, C.A. Cambardella, T.B. Moorman, J.H. Prueger, and M.A. Smith. 1999. Water quality in Walnut Creek watershed: Setting and farming practices. Journal of Environmental Quality 28:11-24.

Heathman, G.C., M. Larose, and J.C. Ascough. 2009. Soil and Water Assessment Tool evaluation of soil and land use geographic information system data sets on simulated stream flow. Journal of Soil and Water Conservation 64(1):17-32, doi:10.2489/jswc.64.1.17.

Hershfield, D.M. 1961. Rainfall frequency atlas of the United States. Washington, DC: Weather Bureau, US Department of Commerce.

Hively, W.D., C.J. Hapeman, L.L. McConnell, T.R. Fisher, C.P. Rice, G.W. McCarty, A.M. Sadeghi, D.R. Whitall, P.M. Downey, G.T. Niño de Guzmán, K. Bialek-Kalinski, M.W. Lang, A.B. Gustafson, A.J. Sutton, K.A. Sefton, and J.A. Harman Fetcho. 2011. Relating nutrient and herbicide fate with landscape features and characteristics of 15 subwatersheds in the Choptank River watershed. Science of the Total Environment 409(19):3866-3878.
Irwin, R.W., and H.R. Whitely. 1983. Effects of land drainage on stream flow. Canadian Water Resources Journal 8:88-103.

Istok, J.D., and G.F. Kling. 1983. Effect of subsurface drainage on runoff and sediment yield from an agricultural watershed in western Oregon, USA. Journal of Hydrology 65:279-291.

James, L.G. 1988. Principles of Farm Irrigation System Design. New York: John Wiley and Sons.

Karlen, D.L., M.D. Tomer, J. Neppel, and C.A. Cambardella. 2008. A preliminary watershed scale soil quality assessment in north central Iowa, USA. Soil and Tillage Research 99(2):291-299.

Keller, C.K., C.N. Butcher, J.L. Smith, and R.M. Allen-King. 2008. Nitrate in tile drainage of the semiarid Palouse basin. Journal of Environmental Quality 37(2):353-361.

King, K.W., P.C. Smiley, B.J. Baker, and N.R. Fausey. 2008. Validation of paired watersheds for assessing conservation practices in the Upper Big Walnut Creek watershed, Ohio. Journal of Soil and Water Conservation 63(6):380-395, doi:10.2489/jswc.63.6.380.

King, K.W., P.C. Smiley Jr., and N.R. Fausey. 2009. Hydrology of channelized and natural headwater streams. Hydrological Sciences Journal 54(5):929-948.

King, K.W., M.R. Williams, and N.R. Fausey. 2015. Contributions of systematic tile drainage to watershed phosphorus transport. Journal of Environmental Quality 44:486-494.

King, K.W., M.R. Williams, and N.R. Fausey. 2016. Effect of crop type and season on nutrient leaching to tile drainage under a corn-soybean rotation. Journal of Soil and Water Conservation 71(1):56-68, doi:10.2489/ jswc.71.1.56.

Lee, S., A.M. Sadeghi, G.W. McCarty, C. Baffaut, S. Lohani, L.F. Duriancik, A.L. Thompson, I. Yeo, and C. Wallace. 2018. Assessing the suitability of the Soil Vulnerability Index (SVI) classification scheme using the SWAT model. CATENA 167:1-12.

Lee, S., I.Yeo, A.M. Sadeghi, G.W. McCarty, W.D. Hively, and M.W. Lang. 2016. Impacts of watershed characteristics and crop rotations on winter cover crop nitrate-nitrogen uptake capacity within agricultural watersheds in the Chesapeake Bay region. PLoS ONE 11(6):e0157637.

Lentz, R.D., D.L. Carter, and S.V. Haye. 2018. Changes in groundwater quality and agriculture in forty years on the Twin Falls irrigation tract in southern Idaho. Journal of Soil and Water Conservation 73(2):107-119, doi:10.2489/jswc.73.2.107.

Lizotte, R.E., L.M.W.Yasarer, M.A. Locke, R.L. Bingner, and S.S. Knight. 2017. Lake nutrient responses to integrated conservation practices in an agricultural watershed. Journal of Environmental Quality 46(2):330-338.

Lohani, S., C. Baffaut,A.L.Thompson, N.Aryal, R.L.Bingner, D.L. Bjorneberg, D.D. Bosch, R.B. Bryant, A. Buda, S.M. Dabney, A.R. Davis, L.F. Duriancik, D.E. James, K.W. King, P.J.A. Kleinman, M. Locke, G.W. McCarty, L.A. Pease, M.L. Reba, D.R. Smith, M.D. Tomer, T.L. Veith, 
M.R. Williams, and L.M.W. Yasarer. 2020. Performance of the Soil Vulnerability Index with respect to slope, digital elevation model resolution, and hydrologic soil group. Journal Soil and Water Conservation 75(1):12-27, doi:10.2498/jswc.75.1.12.

McCarty, G.W., L.L. McConnell, C.J. Hapeman, A. Sadeghi, C. Graff, W.D. Hively, M.W. Lang, T.R. Fisher, T. Jordan, C.P. Rice, E.E. Codling, D. Whitall, A. Lynn, J. Keppler, and M.L. Fogel. 2008. Water quality and conservation practice effects in the Choptank River watershed. Journal of Soil and Water Conservation 63(6):461-474, doi:10.2489/jswc.63.6.461.

Pease, L.A., K.W. King, M.R. Williams, G.A. LaBarge, E.W. Duncan, and N.R. Fausey. 2018. Phosphorus export from artificially drained fields across the Eastern Corn Belt. Journal of Great Lakes Research 44(1):43-53.

Reba, M.L., and N. Aryal. 2018a. Agricultural Practice Monitoring and Evaluation, Year Three (2017) Annual Report. AR0311401-01 and AR031401-02. Jonesboro, AR: USDA Agricultural Research Service.

Reba, M.L., and N. Aryal. 2018b. Agricultural Practice Monitoring and Evaluation, Year Four (2017) Annual Report. AR 1111301-01, AR1111301-02 and AR1111301-03. Jonesboro, AR: USDA Agricultural Research Service.

Saleh, A., E. Osei, D.B. Jaynes, B. Du, and J.G. Arnold. 2007. Economic and environmental impacts of LSNT and cover crops for nitrate-nitrogen reduction in Walnut Creek watershed, Iowa, using FEM and enhanced SWAT models. Transactions of the ASABE 50(4):1251-1259.

Skaggs, R.W., M.A. Brevé, and J.W. Gilliam. 1994. Hydrologic and water quality impacts of agricultural drainage. Critical Reviews in Environmental Science and Technology 24(1):1-32.

Smith, D.R., K.W. King, L. Johnson, W. Francesconi, P. Richards, D. Baker, and A.N. Sharpley. 2015. Surface runoff and tile drainage transport of phosphorus in the Midwestern United States. Journal of Environmental Quality 44(2):495-502.

Smith, D.R., S.J. Livingston, B.W. Zuercher, M. Larose, G.C. Heathman, and C. Huang. 2008. Nutrient losses from row crop agriculture in Indiana. Journal of Soil and Water Conservation 63(6):396-409, doi:10.2489/ jswc.63.6.396.

Smith, D.R., R.S. Wilson, K.W. King, M. Zwonitzer, J.M McGrath, R.D. Harmel, R.L. Haney, and L.T. Johnson. 2018. Lake Erie, phosphorus, and microcystin: Is it really the farmer's fault? Journal of Soil and Water Conservation 73(1):48-57, doi:10.2489/jswc.73.1.48.

Soil Survey Staff. 2018. Web Soil Survey. Washington, DC: USDA Natural Resources Conservation Service. https://websoilsurvey.nrcs.usda.gov/.

Stamm, C., H. Flühler, R. Gächter, J. Leuenberger, and H. Wunderli. 1998: Preferential transport of phosphorus in drained grassland soils. Journal of Environmental Quality 27(3):515-522.
Strock, J.S., C. Hay, M.J. Helmers, K.A. Nelson, G.R. Sands, R.W. Skaggs, and K.R. Douglas-Mankin. 2018. Advances in drainage: Selected works from the Tenth International Drainage Symposium. Transactions of the ASABE 61(1):161-168.

Thompson, A.L., C. Baffaut, S. Lohani, L.F. Duriancik, M.L. Norfleet, and K. Ingram. 2020. Purpose, development, and synthesis of the SoilVulnerability Index for inherent vulnerability classification of cropland soils. Journal Soil and Water Conservation 75(1):1-11, doi:10.2489/ jswc.75.1.1.

Tomer, M.D., D.E.James, and T.M. Isenhart. 2003. Optimizing the placement of riparian practices in a watershed using terrain analysis. Journal of Soil and Water Conservation 58(4):198-206.

Tomer, M.D., T.B. Moorman, and C.G. Rossi. 2008. Assessment of the Iowa River's South Fork watershed: Part 1. Water quality. Journal of Soil and Water Conservation 63(6):360-370, doi:10.2489/ jswc.63.6.360.

Tomer, M.D., C.G.Wilson,T.B. Moorman, K.J. Cole, D. Heer, and T.M. Isenhart. 2010. Source-pathway separation of multiple contaminants during a rainfall-runoff event in an artificially drained agricultural watershed. Journal of Environmental Quality 39:882-895

USDA ARS (Agricultural Research Service). 2013. Science documentation: Revised Universal Soil Loss Equation Version 2. Washington, DC: USDA Agricultural Research Service.

USDA NASS (National Agricultural Statistics Service). 2016. Cropland Data Layer. Washington, DC: USDA National Agricultural Statistics Service. https://nassgeodata.gmu. edu/CropScape/.

USDA NRCS (Natural Resources Conservation Service). 2012. Assessment of the effects of conservation practices on cultivated cropland in the Upper Mississippi River basin. Conservation Effects Assessment Project (CEAP) Final Report. Washington, DC: USDA Natural Resources Conservation Service.

USDA NRCS. 2018. CEAP (Conservation Effects Assessment Project) Soil Vulnerability Index for Cultivated Cropland (SVI-cc) User Guide, Version 1.12. Washington, DC: USDA Natural Resources Conservation Service.

Wang, X., J.R. Williams, P.W. Gassman, C. Baffaut, R.C. Izaurralde, J. Jeong, and J.R. Kiniry. 2012. EPIC and APEX: Model use, calibration, and validation. Transactions of the ASABE 55(4):1447-1462.

Williams, M.R., K.W. King, and N.R. Fausey. 2015. Contribution of tile drains to basin discharge and nitrogen export in a headwater agricultural watershed. Agricultural Water Management 158(3):42-50.

Wischmeier, W.H., and D.D. Smith. 1978. Predicting rainfall losses-A guide to conservation planning. Agriculture Handbook No. 537. Washington, DC: US Government Printing Office.
Wren, D.G., J.M. Taylor, J.R. Rigby, M.A. Locke, and L.M.W. Yasarer. 2019. Short term sediment accumulation rates reveal seasonal time lags between sediment delivery and deposition in an oxbow lake. Agriculture, Ecosystems and Environment 281:92-99.

Yasarer, L.M.W., S. Lohani, R.L. Bingner, M.A. Locke, C. Baffaut, and A.L. Thompson. 2020. Assessment of the Soil Vulnerability Index and comparison with AnnAGNPS in two Lower Mississippi River Basin watersheds. Journal Soil and Water Conservation 75(1):53-61, doi:10.2489/jswc.75.1.53. 